\title{
Nieve en el fondo de Erwin Díaz
}

Santiago de Chile: Surada Ediciones, 2007, 85 páginas.

Martín Ríos López Universidad Complutense de Madrid. Madrid, España Investigador permanente de CENALTES mirios@estumail.ucm.es

Casi sin duda alguna que el nombre de Erwin Díaz, a todo buen lector de poesía, no debiera resultar extraño. Se le tendrá presente, al menos, por un motivo poético de particular importancia. Traigo a colación ese motivo. Se recordará que en los primeros años de la década del noventa, siglo XX, aparece editada por el Fondo de Cultura Económica Los dominios perdidos. Esta antología poética recoge de modo brillante, a mí entender, la esencia más destacada de Jorge Teillier, uno de los más importantes poetas que nuestro país ha dado. Sin embargo, el merito de la puesta a punto de ese rescate esencial recae, sin duda alguna, en las capacidades de un lector que ha logrado comprender verdaderamente el ethos poético ofrecido por Teillier. Este es un merito, entonces, que pertenece de modo absolutamente particular a Erwin Díaz.

Al merito anterior se agrega que ha dirigido la revista de poesía y cuento El organillo y el diario de poesía Ocio. Además es autor de la muestra de 16 poetas chilenos que data de 1987 y también de la antología Poesía chilena de hoy. De Parra a nuestros días (10 a edición, 2005), editada por Metales Pesados.

En esta oportunidad Erwin Díaz nos ofrece un nuevo texto que lleva por nombre Nieve en el fondo. Este texto está compuesto por cuatro momentos, a saber: I.- Nieve en el fondo, II.- Granizos, III.- Más allá de uno y IV.- Sentidos y latidos.

En la antesala a abrir el texto de Díaz, quizás, y nótese que digo sólo quizás, más de alguien podría dejarse llevar por la seducción de un prejuicio. Un prejuicio que viene dado por el camino poético recorrido por su autor y que de un modo u otro ha quedado destacado y descrito en las primeras 
líneas de esta reseña. Si nos dejamos conquistar por ese prejuicio, corremos el peligro de sostener la falsa idea de que, lo que viene a continuación, no son más que versos que están haciendo guiños a la modulación poética de Teillier. Una modulación guiñoza que, como en muchos casos, queda presa en lo grotesco de su gesto. En este sentido, esa escritura no sería más que un simple remedo, un deseo, que como tal, nunca alcanza el objeto deseado; sería no más que una hipócrita puesta en escena, esto es, y para decirlo de modo sencillo, un montaje, pero en el más peyorativo de los sentidos. Con todo, un carente y desaliñado registro poético que no alcanzaría para más que una anécdota de su particular existencia.

Sin embargo, debo afirmar que una grata sorpresa inundará el espíritu de todo aquel que se eche a correr por esas páginas. Al poco andar el lector se encontrará con una propuesta fresca y sutil, pero por sobre todo honesta. Una propuesta que es efectivamente honesta, insisto, porque desea hablar en nombre propio y con una voz propia. Ciertamente que los temas que recorren fantasmagóricamente sus páginas son temas que rápidamente se pueden reconocer: la soledad, la alegría, la tristeza, la melancolía de tiempos pasados, el amor, el desamor, la felicidad, etc. Con todo debo decir que en ningún caso la poesía de Díaz cae en lugares comunes o en los típicos clichés, sino muy por el contrario, de ahí su excepcional mérito, puesto que logra ponernos en contacto, por medio de esas mismas experiencias, en comunión con el gran misterio de la existencia. Con la sutileza y la sagacidad que le es propia a este libro, cada poema con su enjambre de versos se termina por convertir en una especie de Ramas iluminadas / Nieve en el fondo / De la tierra (34)

Desde ese hermoso enjambre de palabras, palabras un poco de aire movidos por los labios ("Despedida", de Jorge Teillier. 1961. El árbol de la memoria), como nos dirá Teillier, Díaz nos hace afrontar la Nieve en el fondo que todos tenemos: la soledad. Sin embargo, y para ser honestos con el texto, debemos decir que las palabras de Díaz no se quedan mascando el sin sabor que da una fútil victimización de la existencia, puesto que reconoce que en nuestra propia experiencia de la soledad hay otro que en su propia soledad comulga con la mía. Hermosamente hace sentir que esa comunión con otro es en plural, esto es, con otros. Lo paradójico es que la experiencia del amor es quien termina por ofrecer una suerte de salida al solipsismo de la existencia a través del reconocimiento del mismo padecimiento en otro. 
La soledad no existe

Otro igual que yo

Ama la misma mujer (37)

Esta y otras sorpresas nos ofrece este texto de Díaz, todas gratas, por cierto, a quien desee circular entre sus hojas. De seguro que al acabar la última página el lector se quedará con ganas de más, y ése es, sin duda alguna, síntoma que se tiene un excelente libro entre las manos. 